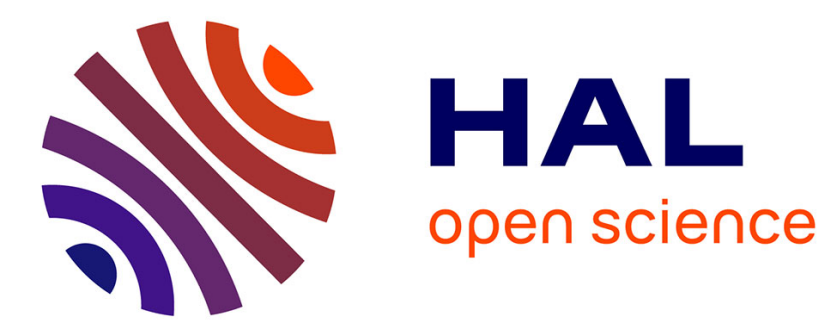

\title{
Post-treatment Study of Iron/Sulfur-containing Compounds in the Wreck of Lyon Saint-Georges 4 (Second Century ACE)
}

Céline Remazeilles, Laure Meunier, Francois Leveque, Nicolas Plasson, Egle Conforto, Marine Crouzet, Philippe Refait, Loïc Caillat

\section{To cite this version:}

Céline Remazeilles, Laure Meunier, Francois Leveque, Nicolas Plasson, Egle Conforto, et al.. Posttreatment Study of Iron/Sulfur-containing Compounds in the Wreck of Lyon Saint-Georges 4 (Second Century ACE). Studies in Conservation, 2019, pp.1-9. 10.1080/00393630.2019.1610608 . hal02345771

HAL Id: hal-02345771

https: / hal-univ-rochelle.archives-ouvertes.fr/hal-02345771

Submitted on 4 Nov 2019

HAL is a multi-disciplinary open access archive for the deposit and dissemination of scientific research documents, whether they are published or not. The documents may come from teaching and research institutions in France or abroad, or from public or private research centers.
L'archive ouverte pluridisciplinaire HAL, est destinée au dépôt et à la diffusion de documents scientifiques de niveau recherche, publiés ou non, émanant des établissements d'enseignement et de recherche français ou étrangers, des laboratoires publics ou privés. 


\section{Post-treatment study of iron/sulfur-containing compounds in the wreck of}

\section{Lyon Saint-Georges 4 ( $2^{\text {nd }}$ century AD).}

Céline Rémazeilles ${ }^{\mathrm{a}}$, Laure Meunier ${ }^{\mathrm{b}}$, François Lévêque $^{\mathrm{c}}$, Nicolas Plasson $^{\mathrm{a}, \mathrm{c}}$, Egle

Conforto $^{\mathrm{a}}$, Marine Crouzet $^{\mathrm{b}}$, Philippe Refait ${ }^{\mathrm{a}}$, Loïc Caillat ${ }^{\mathrm{b}}$

${ }^{a}$ LaSIE, Laboratoire des Sciences de l'Ingénieur pour l'Environnement, UMR 7356 CNRS-La

Rochelle Université, Avenue Michel Crépeau, F-17042 La Rochelle cedex 1, France

${ }^{b}$ Arc-Nucléart, 17 rue des Martyrs F-38054 Grenoble cedex 9, France

${ }^{c}$ LIENSs, Littoral, Environnement et Sociétés, UMR 7266 CNRS-La Rochelle Université, 2 rue

Olympe de Gouges, F-17000 La Rochelle, France.

Corresponding author: Céline Rémazeilles, Tel: 335464583 52, E-mail: cremazei@ univ-lr.fr

\section{Abstract}

A pre-restoration diagnosis revealed a high amount of pyrite in the wood of the Lyon SaintGeorges 4 shipwreck (end of the $2^{\text {nd }}$ century). The occurrence of this phase is supposed to result from the microbiologically influenced corrosion of the iron fasteners. So, all the nails and metallic elements were removed from the remains before treatment and the wreck was consolidated by polyethylene glycol impregnation coupled to a specific desalination process. Treated and non-treated samples extracted from the wreck were studied in order to identify the iron/sulfur-containing compounds present in the wood before and after treatment and figure out its effect. Sample analyses relied on an original approach combining magnetic characterization methods and more common elemental and structural analysis methods. The results showed that the treatment was effective in removing soluble salts. However, a large amount of unstable iron sulfides remained inside the wood.

Keywords : waterlogged wood, shipwreck, PEG, pyrite, greigite, microbiologically influenced corrosion. 


\section{Introduction}

The contamination of waterlogged wood/iron assemblies by iron sulfides is a well known issue in the field of cultural heritage preservation (Mac Leod and Kenna 1990; Sandström et al. 2002, Fors and Sandström 2006; Remazeilles et al 2013). A first diagnosis carried out before restoration on the shipwreck Lyon Saint-Georges 4 revealed a very high amount of pyrite $\left(\mathrm{FeS}_{2}\right)$ inside the wood. Pyrite is considered to occur as the result of the microbiologically influenced corrosion (MIC) of the iron fasteners. This phenomenon is added to the purely electrochemical corrosion process of iron and is promoted by anaerobic sulfide-producing bacteria (SPB). Archaeological wood-iron assemblies aged in restricted oxygen media like waterlogged sediments or sea-/lake-/riverbed are particularly exposed to this phenomenon (Sandström et al. 2001, 2005, Wetherall et al. 2008, Godfrey, Richards, and MacLeod 2011). Anoxic conditions can establish at the surface of the fasteners and wood constitutes an abundant source of nutrients for SPB to develop. In consequence, all the factors and parameters of an effective bioreactor for iron sulfides production are gathered when such composite systems are exposed to wet burial contexts. Once exposed to air, the oxidation of iron sulfides induces dramatic postexcavation damages. These consist in the occurrence of iron/sulfate-containing salts (i.e. melanterite $\left[\mathrm{FeSO}_{4}, 7 \mathrm{H}_{2} \mathrm{O}\right]$, rozenite $\left[\mathrm{FeSO}_{4}, 4 \mathrm{H}_{2} \mathrm{O}\right]$, natrojarosite $\left.\left[\mathrm{NaFe}_{3}(\mathrm{OH})_{6}\left(\mathrm{SO}_{4}\right)_{2}\right]\right)$ (Sandström et al 2001, 2005). Unsightly efflorescence appears on the surface of the wood but the growing of the crystals in the bulk causes mechanical stresses leading to cracks and embrittlement of the organic matter (Fors, Jalilehvand, and Sandström 2011). Oxidation of iron sulfides is also linked to a strong acidification of the medium, particularly harmful for the mechanical resistance of the wood. Acidic conditions favor cellulose and hemicellulose hydrolysis (Farber 1954; Emery and Schroeder 1974; Baker 1974; Hedges 1989; Dedic, Iversen, and Ek 2013). Consequently, physically and chemically affected, the wood ends up losing its mechanical properties compromising the integrity of the whole structure. 
The wreck Lyon Saint-Georges 4 has been excavated from waterlogged sediments and was expected to be exhibited in the Gallo-Roman museum Lugdunum (Lyon, France). The important presence of iron sulfides in the remains proved to be a crucial parameter in the design of a relevant strategy to apply for its preservation. Since no specific preservation treatments exist that are tailored to deal with the threats posed by iron sulfides, a conservation plan can only focus on the best possible way to avoid the side effects caused by the oxidation of iron sulfides. In the present case, it has been decided to invest in a powerful air conditioning system for exhibition, after the ship was consolidated by a polyethylene glycol (PEG) impregnation. Once taken over by the Arc-Nucleart laboratory, the shipwreck was entirely dismantled and as many nails, fasteners and other metallic artefacts as possible were manually removed. The treatment consisting of PEG impregnation coupled to a continuous desalination process was then applied for at least 8 months and up to 2.5 years for the last pieces.

In order to determine the treatment effects, treated and non-treated samples were analyzed, bringing a special care about mineral phases and salts. Some expected iron sulfides like greigite $\left(\mathrm{Fe}_{3} \mathrm{~S}_{4}\right)$ and pyrrhotite $\left(\mathrm{Fe}_{1-\mathrm{x}} \mathrm{S}\right)$ and iron oxides like magnetite $\left(\mathrm{Fe}_{3} \mathrm{O}_{4}\right)$ and maghemite $\left(\mathrm{Fe}_{2} \mathrm{O}_{3}\right)$ are naturally magnetic. This allowed a novel analytical approach to be used, combining classical elemental and structural analysis methods (Environmental scanning electron microscopy coupled to energy dispersive spectroscopy, micro-Raman spectroscopy, X-ray diffraction, Fourier transform infrared spectroscopy) with magnetic measurement methods (magnetic susceptibility measurements and remanent magnetization acquisition curves). This article presents the results obtained owing to the study of wood samples extracted from different areas of the wreck.

\section{Materials and Methods}

\section{The wreck $n^{\circ} 4$}


Sixteen shipwrecks have been discovered in 2003 during a preventive excavation carried out by the French National Institute of Preventive Archaeological Research (INRAP) prior to the construction of an underground car park. The site corresponded to the ancient right bank of the Saône River located now in the Parc Saint-Georges in Lyon (France) (Ayala 2010, 2013). These wrecks were dated from the Roman period ( $1^{\text {st }}$ century AD) to the $18^{\text {th }}$ century (Ayala 2010, 2013; Lavier and Driget 2010). Among the six Gallo-Roman wrecks, three of them were cut out and stored in a lake near-by to await conservation. In 2013, an agreement was reached concerning the Gallo-Roman shipwreck Lyon-Saint Georges n 4 (LSG4) for exhibition in the Gallo-Roman museum Lugdunum. The ARC-Nucléart laboratory was in charge of the restoration and the treatment started in 2014.

LSG4 was one of the best-preserved wrecks but only half of the boat was available, because the other part continued outside the car park wall. It was dated by dendrochronology from the $2^{\text {nd }}$ century (158-185 AD). This flat-bottomed barge similar to other Gallo-Roman examples was made of oak and fir (Lavier and Driget 2010). It was $18.83 \mathrm{~m}$ long for $4.67 \mathrm{~m}$ wide and the assembly of the wooden elements was realized with iron nails (Guyon 2010). The boat was caulked using reused textiles impregnated with tar.

\section{Treatment}

The significant amount of pyrite visually observed on the artifacts just after excavation, presupposing a particular high amount inside the wood, led to the design of a specific stabilization treatment plan. The strategy consisted in a set of tasks aiming to avoid at best pyrite oxidation and possible side effects (efflorescence precipitation, wood acidification, etc.) to occur. The treatment was entirely realized in the ARC-Nucleart laboratory. The very first step consisted in removing all the 2100 nails and metallic elements off the wreck. Then a PEG impregnation was applied combining meanwhile four devices: mechanical filtration, bubbling 
oxygenation, UVC sterilization and chemical filtration as thoroughly described in Caillat and Meunier-Salinas (2016). To improve the system, a one-off addition of citric acid, which is both biodegradable and safe, could be added in order to avoid alkalization of the PEG solution (mainly due to the deionization of the solution) and to maintain $\mathrm{pH}$ between 5 and 6 . This addition proved necessary to limit the development of biofouling at the wood-solution interface, which takes place when the $\mathrm{pH}$ is higher than 7 . This slightly acidic $\mathrm{pH}$ is supposed to prevent the bacteria flora's multiplication.

The treatment was planned for at least eight months using PEG 2000, divided into two fourmonth periods, the first with a concentration of $20 \% \mathrm{wt}$, and the second with a concentration of $35 \%$ wt. High molecular weight PEGs (from 2000) are less hydrophilic than low molecular weight PEGs. For example, PEG 200 or 400 due to a high concentration of polar hydroxyl terminal functions are liquid at room temperature and mobile in the material. They can migrate to the surface and cause staining, deformation of the wood or extensive rewetting in case of high relative humidity $(\mathrm{RH})$ under exposure conditions. PEG 2000 was therefore chosen because of its low reactivity to ambient humidity. It is in the solid state at room temperature and is supposed to consolidate the wood once the treatment is finished and the artifacts dried and exposed to air.

The extraction of all kinds of soluble salts is mandatory to prevent the precipitation of bulky crystals and mechanical damages of the wood after drying the artifacts. During the impregnation, a regeneration system of the solution was applied. This is based on the use of ion-capturing resins capable of lowering ion concentrations in the solution and continuously extracting, by diffusion, the mobile ions contained in the wood. Chemical filtration was performed on a fluidized bed: The solution passes through a column filled with a granular material having a chemical affinity with the substances to be removed and is thus desalinized by percolation. The fluidized bed is contained in a hollow cylinder of a size similar to the filters 
already used in the laboratory. The Dow (C) ion exchange resins used in this device release $\mathrm{OH}^{-}$ and $\mathrm{H}^{+}$, thus avoiding the introduction of other ions into the solution and into the interior of the wood (Amberlite ${ }^{\mathrm{TM}}$ IRA402 OH and IR120 H, Dow Europe GmbH, Switzerland). Such a system, already used during previous treatments, proved its effectiveness in reducing the concentration of soluble salts (Caillat, Meunier-Salinas, and Coignard 2015, Caillat and Meunier-Salinas, 2016).

After PEG impregnation, wood has been completely freeze-dried during one year and a half. And finally, a complementary coring has been carried out around the nails holes and on the down sides of the elements in order to remove the "magnetic wood", due to the presence of remaining metal or magnetic ferrous mineral species.

\section{Analytical procedure}

In order to estimate the effects of the treatment, a sampling was conducted on the wreck, before and after treatment. 72 treated and 13 non-treated samples were provided for the study. Treated samples, all impregnated by PEG, consisted in wood chips coming from different places of the wreck (Figure 1). Chips were scraped from both surfaces of the planks all around holes remaining of the extraction of the nails. Ten of them were still humid and the others were dry. The dry chips presented a grey color. Non-treated samples consisted in a few $\mathrm{cm}^{3}$ random shaped wet wood fragments, which could not be localized in the shipwreck. These contained no nail but a brown external color suggested a contamination of the wood by iron. Each sample was sent in a small minigrip bag and was stored, after reception at the laboratory, in its original packaging at low temperature $\left(-20^{\circ} \mathrm{C}\right)$ until the analysis campaign. Freezing could have damaged the wood, but it proved to be effective to avoid the transformation of oxygen-sensitive mineral phases like iron sulfides, which was our main concern. During the analysis campaign, 
the samples were tentatively stored at $-4^{\circ} \mathrm{C}$ in order to prevent growth of mold. The $\mathrm{pH}$ was measured on all samples.

Magnetic susceptibility measurements were performed for a general evaluation of the magnetic minerals content. Remanent magnetization acquisition curves were acquired for identification of mineral species according to their magnetic properties. Wood and water do not interfere in the measure of remanence, consequently the magnetic properties measured from the wood are given by the magnetic mineral phases trapped in it. Magnetic susceptibility was measured only on the treated samples. Isothermal remanant magnetization (IRM) and backfield curves were acquired for 32 samples ( 28 treated samples and 4 non-treated samples). 16 of them (12 treated samples and 4 non-treated samples) were studied by elemental analysis and structural characterization methods (Environmental scanning electron microscopy coupled to energy dispersive spectroscopy, micro-Raman spectroscopy, X-ray diffraction). These samples were chosen because of their intense magnetic susceptibility signal. White concretions observed and extracted from some samples were analyzed by Fourier transform infrared spectroscopy.

$\mathrm{pH}$ measurements were performed on moistened chips (treated samples) and on wet wooden slices freshly cut from the non-treated samples using a surface electrode (Sentix Sur, WTW) and a pHmeter (PHM210, Radiometer analytical) calibrated using $\mathrm{pH}=4.00$ and $\mathrm{pH}=$ 7.00 buffer solutions (VWR).

Magnetic susceptibility was measured with a KLY4 (Agico) magnetic susceptibility meter. IRM and backfield curves were acquired up to 3T thanks to a MMPM10 Magnetic Measurements pulse magnetizer (Magnetic Measurements Ltd.) and measured with a JR6 (Agico) spinner magnetometer.

Prior to elemental and structural analysis, wood samples were observed with a stereomicroscope (Leica, M165C) for a preliminary morphological approach and in order to locate areas of interest for microanalysis. 
Electronic high-resolution micrographs and elemental analysis spectra were obtained with an environmental scanning electron microscope (ESEM, Quanta 200 FEG, FEI) coupled with an EDAX Genesis EDS system for X-Ray microanalysis. The observations were made in environmental mode, low pressure (0.002 atm) and with an acceleration voltage varying between 15 and $20 \mathrm{kV}$. This experimental method requires no preparation for non-conductive materials and wood samples were placed without any preparation in the analysis chamber.

Micro-Raman spectroscopy analysis ( $\mu$-RS) was carried out with a High Resolution LabRAM HR spectrometer (Jobin Yvon) equipped with a microscope (BX41, Olympus), a x50 objective and a Peltier-based cooled charge coupled device detector. The laser power was lowered in order to prevent the transformation of heat-sensitive mineral phases. Spectra were recorded with the LabSpec software at a resolution of $0.2 \mathrm{~cm}^{-1}$. The samples were analyzed with an excitation wavelength of $632.82 \mathrm{~nm}$.

X-ray diffraction (XRD) experiments were performed directly on the wood samples placed in the sample holder and exposed to the X-ray beam (wavelength $\lambda_{\mathrm{Co}-\mathrm{K} \alpha}=0.17903 \mathrm{~nm}$, EQUINOX 6000 diffractometer, INEL). For the non-treated samples, a freshly cut wet slice was analyzed. The diffraction patterns were processed with the Match! software (Cristal Impact) including the COD database (Crystallography Open Database).

Infrared spectra were acquired from 4000 to $400 \mathrm{~cm}^{-1}$ with a Fourier transform infrared (FT-IR) iS50 spectrometer (Thermo) using an attenuated total reflectance (ATR) Smart iTX accessory equipped with a diamond crystal. The background was performed with air and the spectra corresponded to an accumulation of 64 scans (resolution of $4 \mathrm{~cm}^{-1}$ ).

\section{Results and discussion}

\section{Preliminary measurements}


The $\mathrm{pH}$ measurements of the non-treated samples led to a mean value of $3.3 \pm 0.5$ while the treated samples indicated an increase of the mean value up to $5.0 \pm 0.5$. An effect of the treatment consisted then in removing soluble acids, either organic when associated to the cellulose decay or resulting from chemical mechanisms implying iron sulfides.

The magnetic susceptibility measured only on the treated samples was heterogeneous, ranging from $17.610^{-6}$ SI to $0.123 \mathrm{SI}$, partly induced by the large variation of volume of sample analysis arbitrary considered of $1 \mathrm{~cm}^{3}$. The provided samples were not supposed to contain traces of metal. So, this signal was considered to be due to magnetic corrosion products of the iron fasteners remaining in the wood even after treatment. A tendency could be highlighted, the most magnetic samples are those of zones S2 and S4 (Figure 1). The measurements relating to zones S6 and S1 are very heterogeneous but show that the samples are much less magnetic. The few samples of zone S5 are also not very magnetic. In addition, the samples extracted from the sole are generally much more magnetic than those extracted from the floor.

\section{Analysis of iron sulfides and other corrosion products of iron}

The backfield IRM curves of the 32 treated samples are gathered in Figure 2 (solid+square black curves). The thick solid+dot curve corresponds to the standard curve of single-domain greigite (Jiang et al 2001, Roberts et al 2011). Two groups can be distinguished. Group 1 corresponds to curves closed to the reference, showing magnetic properties exclusively due to single-domain greigite particles. Group 2 shows curves significantly different from the reference. They actually correspond to a mixture of greigite and magnetite $\left(\mathrm{Fe}_{3} \mathrm{O}_{4}\right)$. All samples of group 2 contain greigite and a majority of them contain magnetite in addition. So, considering the dispersed extraction areas represented in Figure 1, it can be considered that greigite is present in the whole shipwreck. 
Pyrite has been also largely detected. This phase has been observed in each sample by optical microscopy. As shown in Figures $3 a$ and 3b, golden crystals and framboids of pyrite were observed either scattered or agglomerated in the wood. Pyrite is non ferromagnetic and cannot be identified by magnetic measurement techniques. However, this phase has been detected in abundance by ESEM, $\mu \mathrm{RS}$ and XRD. Typical ESEM micrographs acquired in chemical contrast are represented in Figure 4. In Figures $4 a$ and 4b, pyrite crystals appear in very bright contrast compared to the wood and are localized along the channels of the wood. They are characterized by octahedral and cubic shapes and by framboids. Moreover, EDS spectra (not shown) revealed that these crystals were composed of sulfur and iron with an average $\mathrm{Fe} / \mathrm{S}$ atomic ratio equal to $0.50 \pm 0.02$, consistent with a $\mathrm{FeS}_{2}$ chemical formula. As an example, a typical Raman spectrum is also represented in Figure 4c. Sometimes, black veins could be observed by optical microscopy in wooden chips (Figure 5a). Figure 5b shows an ESEM micrograph acquired in a zone corresponding to a black vein where cubic and octahedral pyrite crystals are associated with agglomerates of submicronic crystals. These agglomerates provided a $\mathrm{Fe} / \mathrm{S}$ atomic ratio varying from 0.76 to 0.80 . The analysis by micro-Raman spectroscopy of this same area revealed the presence of greigite (Figure 5c), confirming the presence of this phase.

The origin of magnetite can be questioned because this phase was not detected in another ancient shipwreck previously studied. Dated from the $4^{\text {th }}$ century and analyzed just after excavation, the wreck of Mandirac (Narbonne, France) revealed an abundant presence of pyrite and greigite but no magnetite (Remazeilles et al 2016). In the present case, the presence of magnetite in LSG4 is assumed to be linked to the ten years long storage of the remains in the lake, waiting for restoration (see "The shipwreck $n^{\circ} 4$ " part). Diatoms were observed by ESEM in some chips (Figures 6a and 6b) and were characterized by their silicate skeleton (Figure 6c). These microalgae come also probably from the lake instead of from the sediments where the 
wreck has been excavated because they testify of an $\mathrm{O}_{2}$-rich medium. Consequently, magnetite could result from the transformation of the $\mathrm{O}_{2}$-sensitive greigite (Bourdoiseau et al. 2008, Bourdoiseau et al. 2011). Moreover, once the remains immersed in the lake, the on-going MIC process of the nails could have been converted into a process exclusively controlled by $\mathrm{O}_{2}$, favoring the occurrence of iron oxides like magnetite as corrosion products instead of iron sulfides.

These results demonstrate the relevance of the applied analytical methodology and the contribution of magnetic methods, little exploited in this kind of context. Pyrite and greigite were the only iron sulfides detected in LSG4 samples. Pyrite was identified in all studied samples by ESEM-EDS, $\mu$ RS and XRD. Greigite could be detected by the same methods and magnetic characterization methods too. The latter are very sensitive for the detection of magnetic species and confirmed the presence of greigite in each sample. It can then be assumed that both iron sulfides were present in the entire wreck. The presence of magnetite $\left(\mathrm{Fe}_{3} \mathrm{O}_{4}\right)$ was revealed only by magnetic measurements methods, which also determined that it consisted in nanocrystals. Its nanometric feature and/or its presence in very small amounts could explain that this phase was not detected by elemental and structural analysis methods. Magnetic methods analyze in the bulk and bring representative results from the whole sample whereas ESEM-EDS, $\mu \mathrm{RS}$ and XRD are local and/or surface analysis methods. However, magnetic methods restrain the detection of mineral species to magnetic ones. This is not the case for the other methods allowing potentially the detection of a wider range of minerals.

\section{Effect of the PEG treatment}

PEG was clearly observed by FTIR spectroscopy and XRD, as shown in Figures 7a and 7b where the signals of non-treated wood, treated wood and PEG are displayed. The IR spectrum of the non-treated wood (Figure 7a) is typical of a wood in a bad state of preservation. The 
characteristic bands at 1733, 1373, 1158, 1104, 1027 and $895 \mathrm{~cm}^{-1}$ attributed to polysaccharides are not present, which suggests an important degradation of holocellulose and a matter dominated by lignin (Pizzo et al 2015). In comparison, the IR spectrum of the treated wood is almost identical to the one of polyethylene glycol used for the treatment. The diffraction pattern of the non-treated wood (Figure 7b) shows an important background attributed to the decayed organic matter. However, bands are observed and allow determining the presence of pyrite and gypsum $\left(\mathrm{CaSO}_{4} \cdot 2 \mathrm{H}_{2} \mathrm{O}\right)$. The latter was also detected by ESEM and micro-Raman spectroscopy (Figures 7c and 7d). Non-treated samples were still humid and dried progressively during the experiments leading to the precipitation of this phase, as showed in Figure 7c where grey needle-like crystals composed of sulfur, oxygen and calcium (EDS spectra not shown) are superimposed to a bright pyrite vein. Finally, the diffraction pattern of treated samples showed an intense signal of PEG in addition to pyrite and greigite (Figure 7b) but no gypsum. Gypsum has never been detected in treated samples, like any other sulfated or carbonated salts. In consequence, the treatment proved to be efficient in removing soluble salts. Once dry, the wood is free from hygroscopic species. On the other hand, it had no chemical effect on iron sulfides. Maybe a few of them were removed by leaching but pyrite and greigite are still present in very high amounts after treatment. It is worth to note however that greigite, which is a metastable compound, showed no sign of oxidation during the entire analysis campaign, while experiments were carried out without any protection against air. This was unexpected by the operators because either during the analysis of non-treated samples extracted from waterlogged wrecks or in other completely different circumstances, greigite showed a high reactivity to air and a rapid transformation into ferric oxyhydroxides $(\mathrm{FeOOH})$ and mineral sulfur $\left(\alpha-\mathrm{S}_{8}\right)$ (Bourdoiseau et al. 2011; Remazeilles et al 2013). PEG 2000 was used because of its low reactivity to ambient moisture and acts as a bulking agent, coating wood cell walls as well as microcrystals or microcrystalline clusters remaining inside the artifacts. Consequently, PEG is 
probably constituting a barrier against oxygen and moisture, preserving greigite and pyrite crystals from oxidation. However, the protecting effect could be temporary and last only in the early stages following the treatment. This could indeed be short-lived.

Other kinds of organic matter composing the boat were preserved. Wool, used for watertightness, was identified by FTIR as white concretions, which were observed here and there in samples. In addition to the peaks of PEG, the spectrum of figure 8 shows a doublet at 1644 and $1542 \mathrm{~cm}^{-1}$ attributed respectively to characteristic Amide I and Amide II vibration bands of keratin (Cardamone 2010).

\section{Conclusion}

The presence of many nails used for assembly in the wreck LSG4 and the prior observation of pyrite in the wood considerably complicated the implementation of a conservation strategy. Now, the whole applied treatment did not eliminate iron sulfides. Pyrite and greigite remained in significant amount in the treated samples. However, it proved efficient for wood desalination while sulfates or other soluble salts observed in the non-treated samples were not detected in the treated samples. $\mathrm{O}_{2}$-sensitive greigite was supposed to oxidize during the laboratory analyses session but it remained stable in the treated samples in spite of the exposition to air. This unexpected behavior was attributed to PEG probably sheltering crystals by coating. However, this apparent protective effect could be only temporary and pyrite and greigite keep constituting a threat for the preservation of the wreck. This kind of situation implies that a special attention is to be given to the environmental conditions applied for exhibition, in order to prevent any resumption of iron sulfides oxidation, thanks to a monitoring control system of the atmosphere. In addition, regular controls and a follow-up plan are in preparation to physically go and check the state of the wreck. Today (2018), the treatment is over and the first 
elements were treated four years ago. No acidification was observed on them. The results are rather promising, but vigilance is still required.

\section{Disclosure Statement}

No potential conflict of interest was reported by the authors. 


\section{References}

Ayala, G. 2010. "Historique de la recherche.” Archaeonautica, Les épaves de Saint-Georges Lyon-Ier-XVIIIe siècles. 16:15-23

Ayala, G. 2013. "Lyon, Saint-Georges. Archéologie, environnement et histoire d'un espace fluvial en bord de Saône", In : Paris, Maison des sciences de l'Homme (Ed.), Documents d'archéologie française 106, $440 \mathrm{p}$.

Baker, A.J. 1974. "Degradation of wood by products of metal corrosion." USDA Forest Service research paper FPL 229:1-6.

Bourdoiseau, J.-A., Jeannin, M., Sabot, R., Rémazeilles, C., Refait, Ph. 2008. “Characterisation of mackinawite by Raman spectroscopy: Effects of crystallisation, drying and oxidation". Corrosion Science 50:3247-3255.

Bourdoiseau, J.-A., Jeannin, M., Rémazeilles, C., Sabot, R., and Refait, Ph. 2011. "The transformation of mackinawite into greigite studied by Raman spectroscopy." Journal of Raman Spectroscopy 42:496-504.

Caillat, L., Meunier-Salinas, L., Coignard, M.A. 2015. "Régénération continue des bains de PEG utilisés pour la consolidation des bois archéologiques gorgés d'eau", Techné 42:115-120. 
Caillat, L., Meunier-Salinas, L. 2016. "Regeneration of PEG solutions used for waterlogged wood consolidation" In: E. Williams and E. Hocker, (Eds.) Proceedings of the 13th ICOM-CC Group on Wet Organic Archaeological Materials Conference, 305-310. Florence.

Cardamone, J.M. 2010. "Investigating the microsctructure of keratin extracted from wool: peptide sequence (MALDI-TOF/TOF) and protein conformation (FTIR)" Journal of Molecular Structure 969: 97-105.

Dedic, D., Iversen, T., and Ek M. 2013. "Cellulose degradation in the Vasa: the role of acid and rust." Studies in Conservation 58:308-313.

Emery, J.A. and Schroeder H.A. 1974. "Iron-Catalyzed Oxidation of Wood Carbohydrates." Wood Science and Technology 8:123-137.

Farber, E. 1954. "Chemical Deterioration of Wood in the Presence of Iron. Industrial \& Engineering Chemistry. 46: 1968-1972.

Fellowes, D., and Hagan, P. 2003. Pyrite oxidation: the conservation of historic shipwrecks and geological and palaeontological specimens, Studies in Conservation 48:sup1, 26-38.

Fors, Y., and Sandström, M. 2006. "Sulfur and iron in shipwrecks cause conservation concerns" Chemical Society Review 35:399-415.

Fors, Y., Jalilehvand, F., and Sandström, M. 2011. “Analytical Aspects of Waterlogged Wood in Historical Shipwrecks" Analytical Sciences 27:785-792. 
Godfrey, I., Richards, V., and MacLeod, I. 2011. "The Batavia - Past, Current and future conservation." In: M. Ek, (Ed.) Proceedings of the Chemistry and preservation of waterlogged wooden shipwrecks conference, Shipwrecks 2011. 22-28. Stockholm.

Guevremont, J.M., Elsetinow, A.R., Strongin, D.R., Bebie, J., and Schoonen, M.A.A. 1998. "Structure sensitivity of pyrite oxidation: camparison of the (100) and (111) planes" American Mineralogist 83:1353-1356.

Guyon, M. 2010. "Les Epaves” Archaeonautica, Les épaves de Saint-Georges - Lyon - IerXVIIIe siècles. 16:48-97.

Hedges, J.I. 1989. "The Chemistry of Archaeological Wood" Advances in Chemistry 225:111140.

Hunger, S., and Benning, L. G. 2007. "Greigite: a true intermediate on the polysulfide pathway to pyrite", Geochemical Transactions. doi:10.1186/1467-4866-8-1.

Jiang, W.-H., Chorn-Shern, H., Roberts, A. P., Peacor, D. R. 2001. "Contradictory magnetic polarities in sediments and variable timing of neoformation of authigenic greigite", Earth and Planetary Science Letters 193:1-12.

Lavier, C, and Driget, V. 2010. “L'apport des analyses dendrochronologiques". Archaeonautica, Les épaves de Saint-Georges - Lyon - Ier-XVIIIe siècles. 16:105-135. 
Mac Leod, I.D., and Kenna, C. 1990. "Degradation of Archaeological Timbers by Pyrite: Oxidation of Iron and Sulphur Species." In: P. Hoffmann, (Ed.) Proceedings of the 4th ICOM Group on Wet Organic Archaeological Materials Conference, 133-141. Bemerhaven.

Pizzo, B., Pecoraro, E., Alves, A., Macchioni, N., Rodrigues, J.C. 2015. "Quantitative evaluation by attenuated total reflectance infrared (ATR-FTIR) spectroscopy of the chemical composition of decayed wood preserved in waterlogged conditions" Talanta 131: 14-20.

Rémazeilles, C., Tran, K., Guilminot, E., Conforto, E., and Refait, P. 2013. "Study of Fe(II) sulphides in waterlogged archaeological wood.” Studies in Conservation 58:297-307.

Rémazeilles, C., Lévêque, F., Minjacq, M., Refait, P., Sanchez, C., Jézégou, M-P., 2016. "Characterisation of iron (II) sulfides in wet archaeological woods: the wreck of Mandirac (IV ${ }^{\text {th }}$ century, antique ports of Narbonne, France)" In: E. Williams and E. Hocker, (Eds.) Proceedings of the 13th ICOM-CC Group on Wet Organic Archaeological Materials Conference, 227-236. Florence.

Rimstidt, J.D., and Vaughan, D.J. 2003. "Pyrite oxidation: A state-of-art assessment of the reaction mechanism." Geochimica et Cosmochimica Acta 67:873-880.

Roberts, A. P., Chang, L., Rowan, C. J., Horng, C-S., Florindo, F. 2011. "Magnetic properties of sedimentary greigite $\left(\mathrm{Fe}_{3} \mathrm{~S}_{4}\right)$ : An update", Reviews of Geophysics 49, RG1002, doi :10.1029/2010RG000336. 
Sandström, M., Jalilehvand, F., Persson, I., Gelius U., and Frank, P. 2001. “Acidity and Salt Precipitation on the Vasa; The Sulfur Problem." In: P. Hoffmann, J.-A. Spriggs, T. Grant, et al., (Eds.) Proceedings of the 8th ICOM Group on Wet Organic Archaeological Materials Conference, 67-90. Stockholm

Sandström, M., Jalilehvand, F., Persson, I., Gelius, U., Frank, P., and Hall-Roth, I. 2002. "Deterioration of the Seventeenth-century Warship Vasa by Internal Formation of Sulphuric Acid." Nature 415:893-897.

Sandström, M., Jalilehvand, F., Damian, E., Fors, Y., Gelius, U., Jones, M., and Salomé, M. 2005. "Sulfur Accumulation in the Timbers of King Henry VIII's Warship Mary Rose: A Pathway in the Sulfur Cycle of Conservation Concern." In: H.B. Gray, ed. National Academy of Science of the United States of America, Proceedings, 102:14165-14170. Pasadena.

Wetherall, K.M., Moss, R.M., Jones, A.M., Smith, A.D., Skinner, T., Pickup, D.M., Goatham, S.W., Chadwick, A.V., and Newport, R.J. 2008. "Sulfur and Iron Speciation in Recently Recovered Timbers of the Mary Rose revealed via X-Ray Absorption Spectroscopy.” Journal of Archaeological Science 35:1317-1328. 
Figure captions:

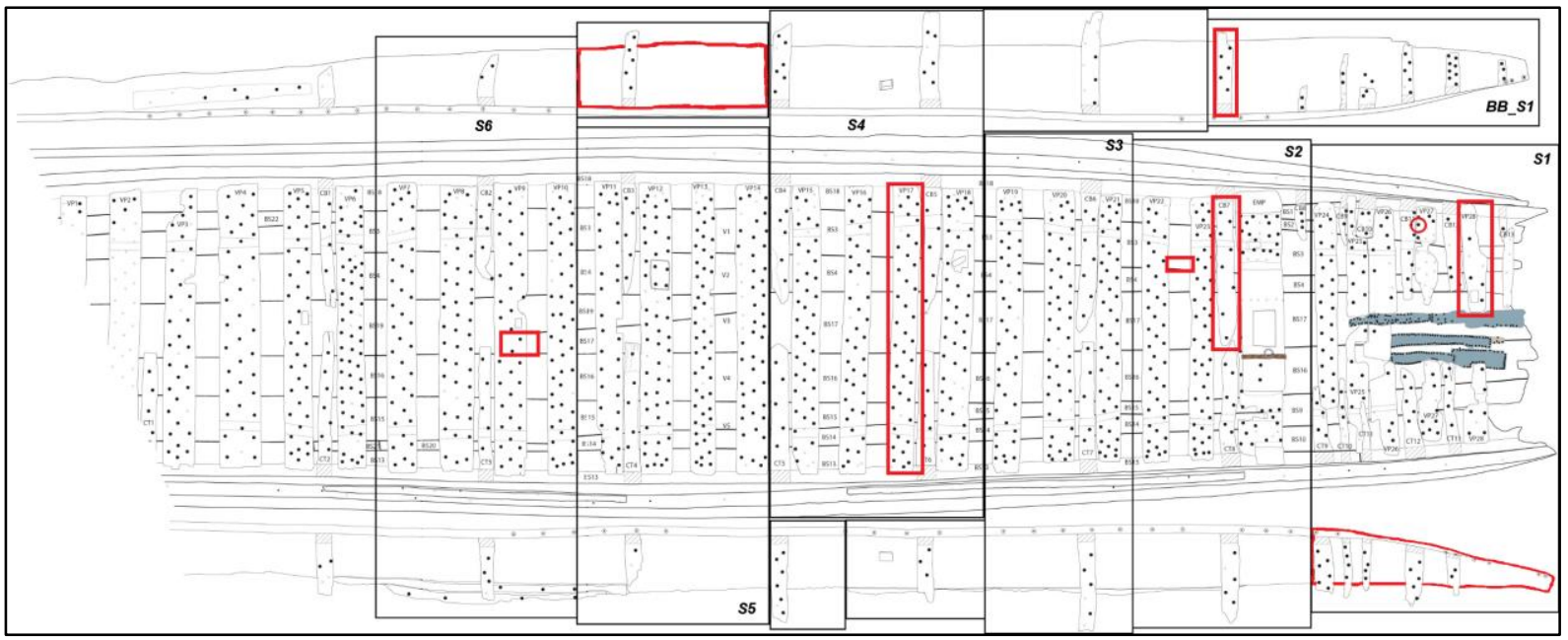

Figure 1: LSG4 shipwreck diagram and sample collection areas (red rectangles) among cut-out parts (S1 to S6).

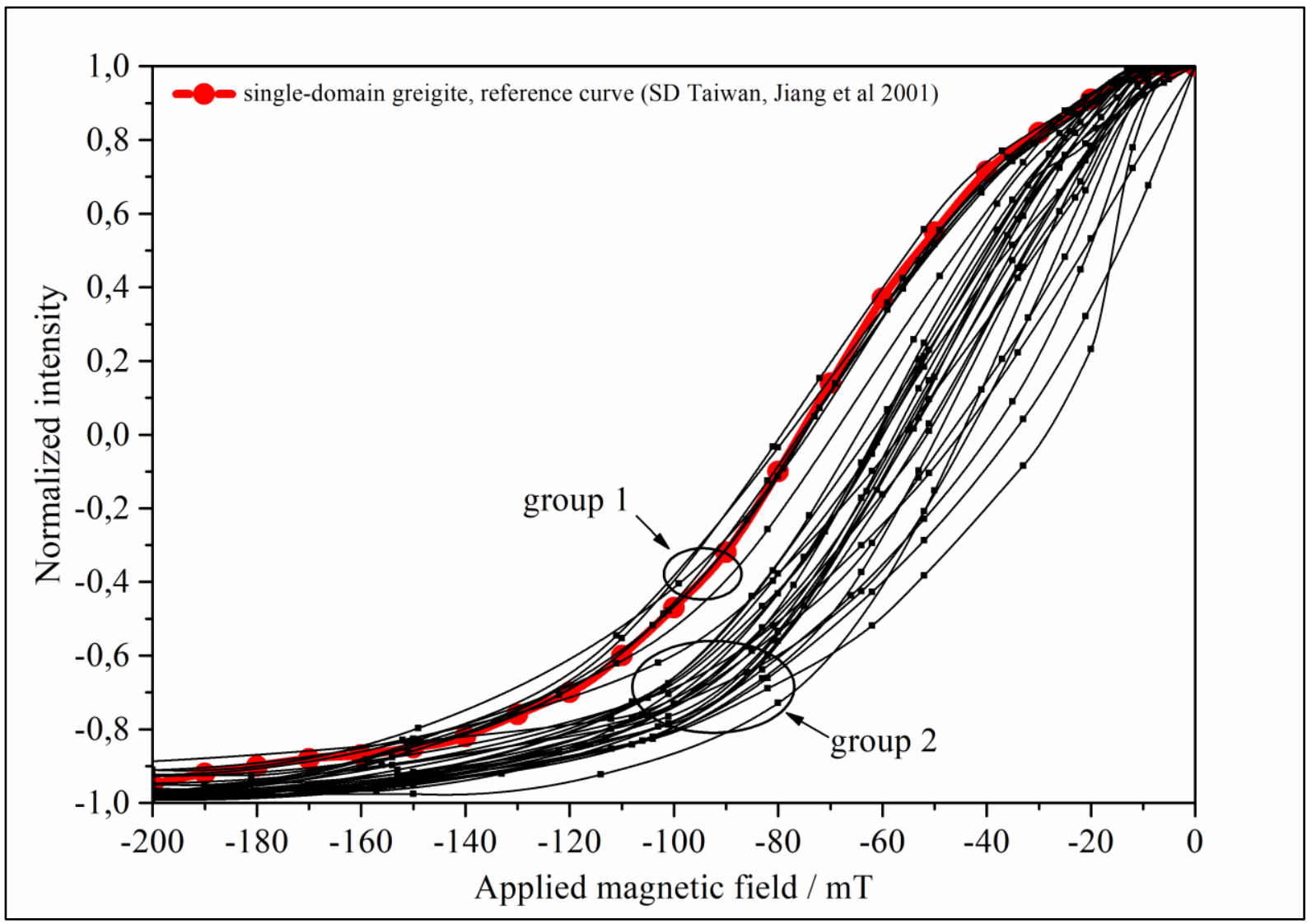

Figure 2: IRM curves (backfield) of wood samples extracted from LSG4 compared to the reference curve of single-domain greigite crystals (dotted curve). Group $1=$ curves 
corresponding to greigite, group $2=$ curves corresponding to a mixture of greigite and magnetite.

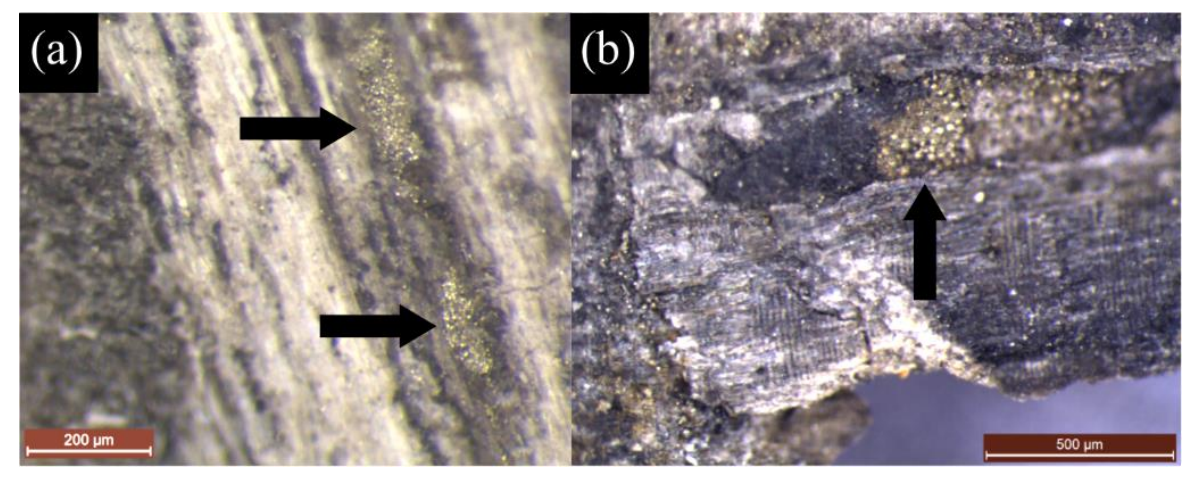

Figure 3: Pyrite crystals in wood fibers observed by optical microscopy.
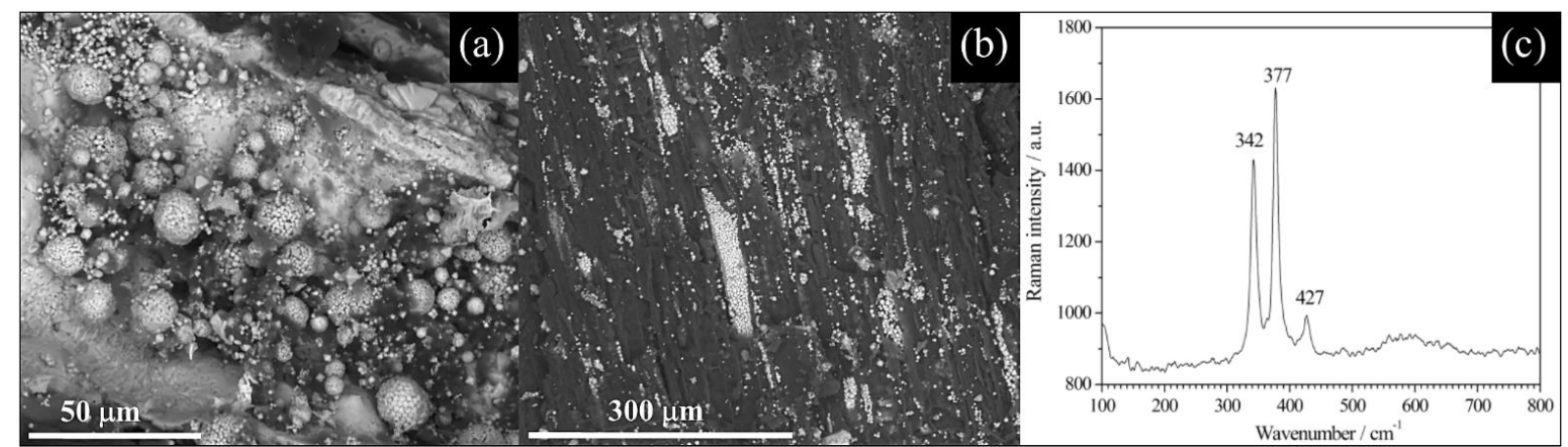

Figure 4: ESEM micrographs of pyrite framboids (a) and crystals (b), Raman spectrum of pyrite (c).

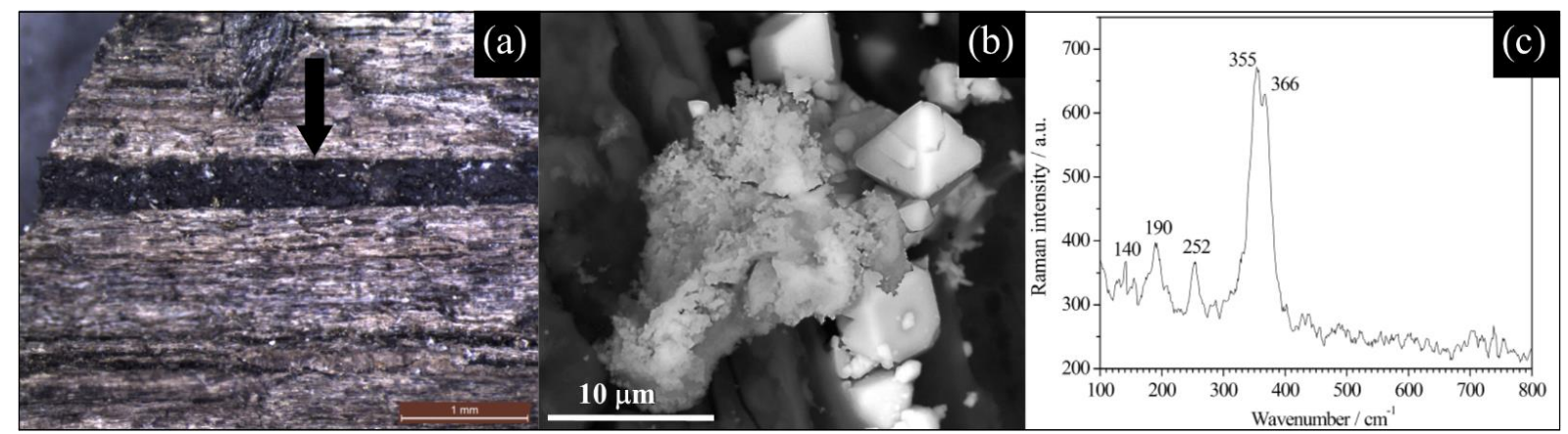

Figure 5: Black vein in wood observed by optical microscopy (a), ESEM micrograph acquired in the arrow zone (b), Raman spectrum of greigite (c). 

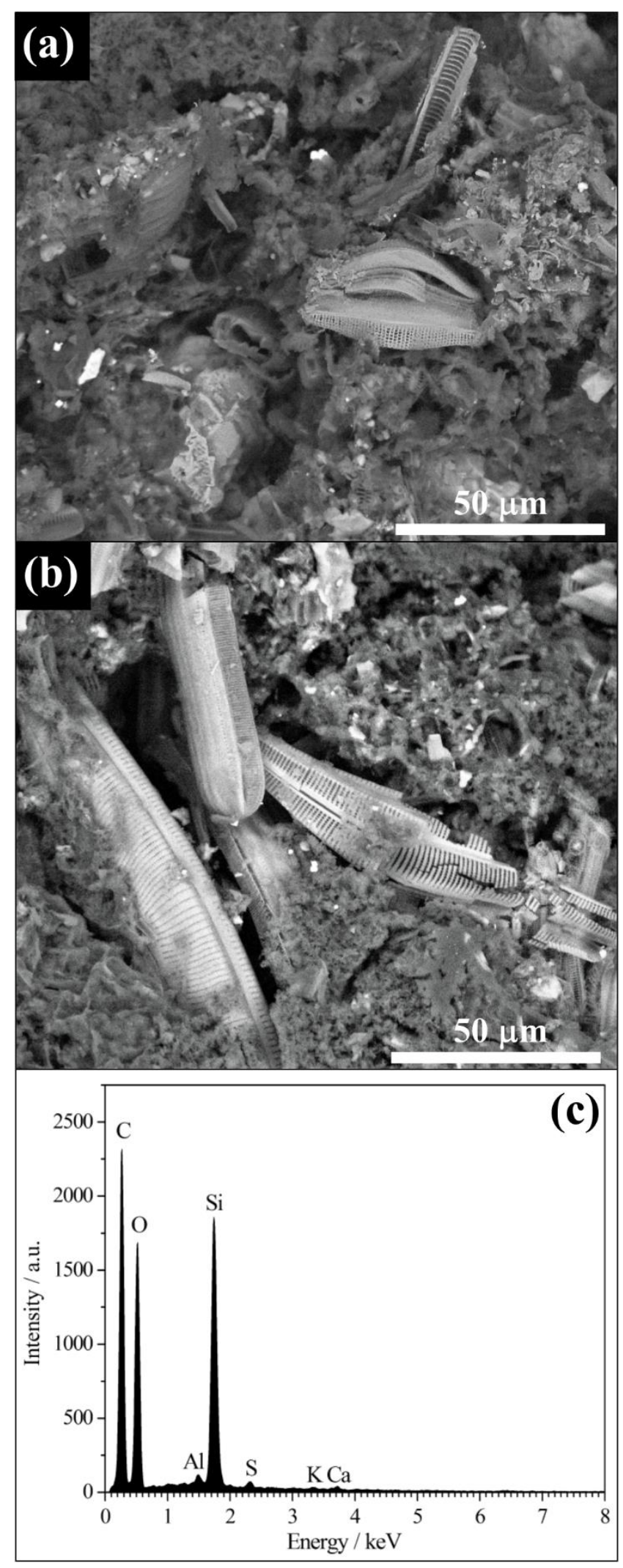

Figure 6: ESEM micrographs of diatoms (a, b), EDS spectrum of a diatom skeleton (c). 

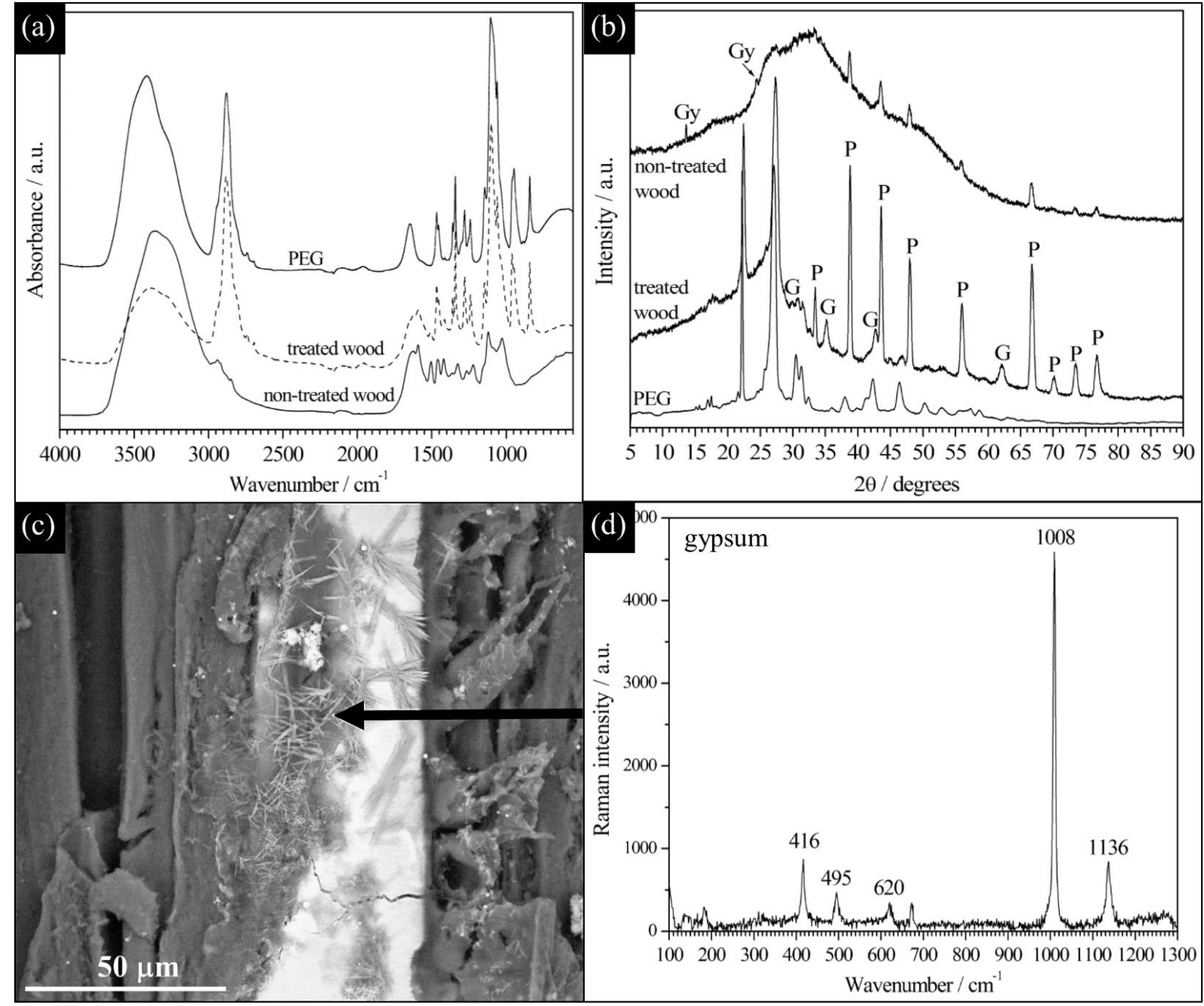

Figure 7: FTIR spectra (a) and XRD patterns (b) of non-treated wood, treated wood and PEG used for treatment. ESEM micrograph of a non-treated sample (c), Raman spectrum of gypsym (d). P = pyrite, $\mathrm{G}=$ greigite, $\mathrm{Gy}=$ gypsum. 


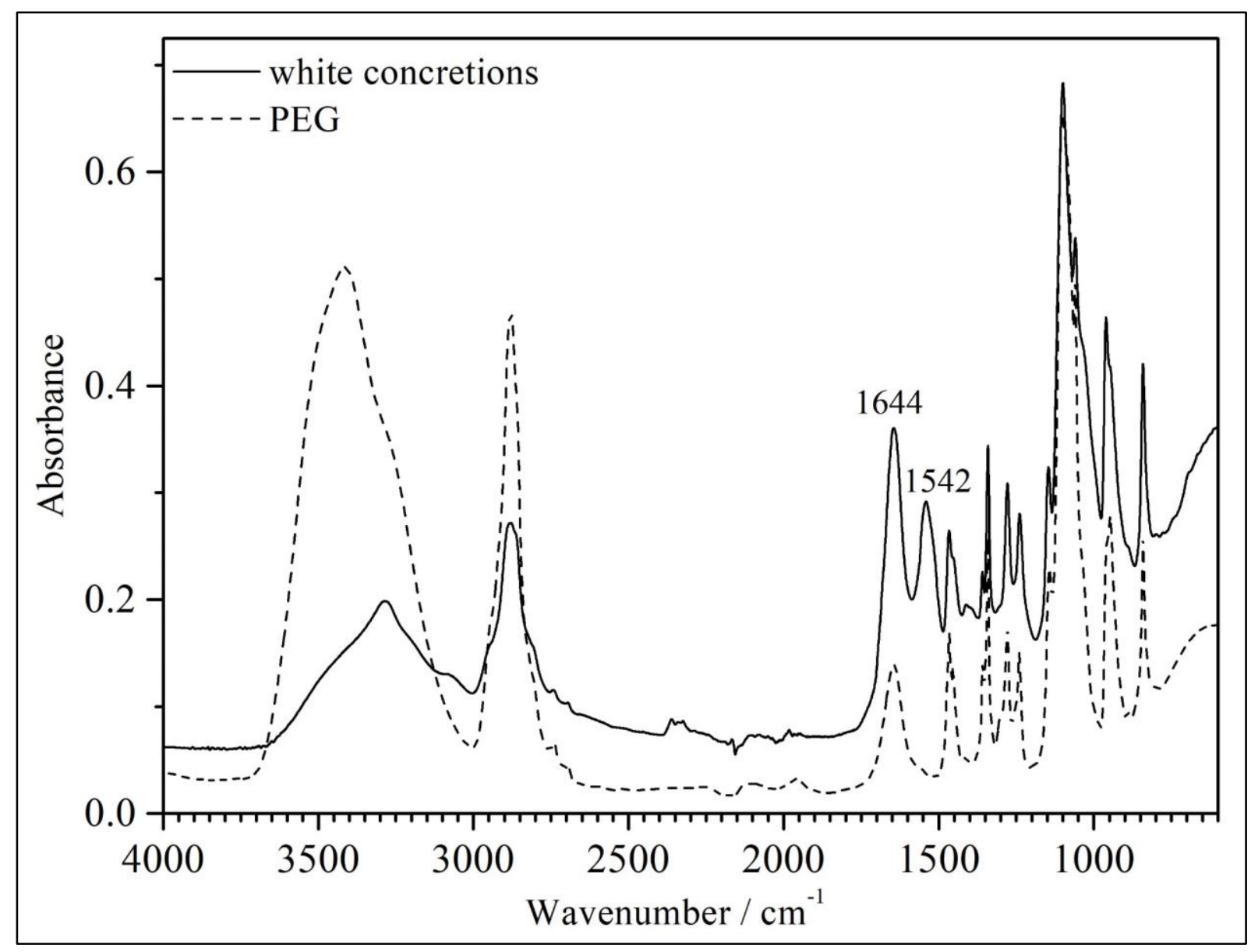

Figure 8: FTIR spectra of white concretions extracted from a wood sample and of PEG. 